\title{
Recovery in Antarctic benthos after iceberg disturbance: trends in benthic composition, abundance and growth forms
}

\author{
N. Teixidó ${ }^{1,3, *}$, J. Garrabou ${ }^{2}$, J. Gutt ${ }^{1}$, W. E. Arntz ${ }^{1}$ \\ ${ }^{1}$ Alfred Wegener Institut für Polar- und Meeresforschung, Columbusstraße, 27568 Bremerhaven, Germany \\ ${ }^{2}$ Marine d'Endoume, Centre d'Océanologie de Marseille, rue Batterie des Lions, 13007 Marseille, France \\ ${ }^{3}$ Present address: Institut de Ciències del Mar (CMIMA-CSIC), Passeig Marítim de la Barceloneta 37-49, \\ 08003 Barcelona, Spain
}

\begin{abstract}
The response of an Antarctic benthic community to iceberg disturbance was investigated using underwater photographs $\left(1 \mathrm{~m}^{2}\right.$ each) on the SE Weddell Sea shelf. This study: (1) characterises composition, coverage, number of patches and area of sessile benthic fauna, (2) describes faunal heterogeneity using MDS ordination and identifies 'structural taxa' of each recovery stage, and (3) analyses changes of growth-form patterns during Antarctic recovery. We observed changes in the space occupation of benthic organisms along the recolonisation stages. Uncovered sediment characterised the early stages ranging from 98 to $91 \%$ of the coverage. The later stages showed high $(70.5 \%)$ and intermediate $(52.5 \%)$ values of benthic coverage, where demosponges, bryozoans and ascidians exhibited a high number of patches and taxa. Several 'structural species' were identified among the stages, and information is provided on their coverage, number of patches and area. Overall, maximum areas of patches increased as recovery proceeded. Early stages were characterised by the presence of pioneer taxa, which only partly covered the bottom sediment but were locally abundant (e.g. the bryozoan Cellarinella spp. and the gorgonian Primnosis antarctica with a maximum coverage of 13 and $3 \%$, and 51 and 30 patches $\mathrm{m}^{-2}$, respectively). Soft bush-like bryozoans, sheet-like sabellid polychaetes, and tree-like sponges, gorgonians, bryozoans and ascidians were the first colonisers. Mound-like sponges and ascidians as well as tree-like organisms with a long lifespan and different reproductive strategies defined the late stages. We conclude by comparing the selected 'structural species' and relating their life-history traits to differences in distribution in the course of Antarctic recovery.
\end{abstract}

KEY WORDS: Antarctica - Benthic communities · Disturbance - Growth forms · Life-history traits · Recovery $\cdot$ Underwater photography $\cdot$ GIS

\section{INTRODUCTION}

Knowledge of the abundance, spatial distribution and diversity of species within a community is fundamental to understanding ecosystems (Sousa 1980, Paine \& Levin 1981, Connell et al. 1997, Newell et al. 1998). Natural disturbance is widely recognised as an important determinant of the occurrence and abundance of species (Dayton 1971, Pickett \& White 1985, Huston 1994, Paine et al. 1998, Sousa 2001). Distur- bance effects on species may depend on their lifehistories, and the dispersal and recruitment patterns of their offspring (e.g. Grassle \& Grassle 1974, Sousa 1980, Connell \& Keough 1985, Giangrande et al. 1994, Hughes \& Tanner 2000).

The unusually deep continental shelf of the Weddell Sea locally exhibits a complex 3-dimensional community with patchy distribution of organisms, intermediate to high diversity and locally extremely high epifaunal biomass (Gutt \& Starmans 1998, Gili et al. 2001, 
Teixidó et al. 2002, Gerdes et al. 2003). The fauna in this area is dominated by a large proportion of benthic suspension feeders such as sponges, gorgonians, bryozoans and ascidians, which locally cover most of the sediment (Gutt \& Starmans 1998, Starmans et al. 1999, Teixidó et al. 2002). Variations in the abundance of these 'structural species' are critical to the organisation of the whole community. The major disturbance affecting the benthos of this deep continental shelf is the grounding and scouring of icebergs (Gutt et al. 1996, Gutt \& Starmans 2001, Knust et al. 2003). They severely disrupt large areas of the seafloor, affecting the physical and biological environment by removing the substrate and eradicating benthic life (Gutt et al. 1996, Gutt 2000).

Changes in composition of benthic communities after iceberg scouring in the SE Weddell Sea shelf have been relatively well studied: from meio- (Lee et al. 2001) to macrobenthos and fish (Gutt et al. 1996, Brenner et al. 2001, Gutt \& Starmans 2001, Gerdes et al. 2003, Gutt \& Piepenburg 2003, Knust et al. 2003). However, despite the importance of 'structural species' in these communities, information is scarce about their abundance and coverage at small spatial scale $\left(1 \mathrm{~m}^{2}\right)$. Studying species abundance of Antarctic benthos in greater detail will greatly contribute to our understanding of the processes underlying the occupation of space along recovery gradients in Antarctic communities and in comprehending the response of these communities to environmental changes. Small spatial scale data may also permit extrapolation and elucidation of general patterns at larger scales.

The abundance of morphological strategies of marine sessile clonal organisms (built up of modules/ polyps or zooids) is predicted to vary as a function of disturbance frequency (both biotic and abiotic), food supply and light (see review by Jackson 1979, Connell \& Keough 1985, Hughes \& Jackson 1985). For example, substrata available after disturbance will be colonised initially by species with stoloniferous or runner-like morphology, which has been interpreted as a fugitive strategy, with early age of first reproduction, high fecundity, rapid clonal growth and high mortality among modules as main life-history traits (Jackson 1979, Coates \& Jackson 1985, Sackville Hamilton et al. 1987). Other growth forms such as sheet, mound and tree characterise areas with low disturbance levels due to predicted higher competitive ability, lower growth rates and lower recruitment rates compared to runner forms (Buss 1979, Jackson 1979, Karlson et al. 1996).

In this study, we examine quantitative changes in the composition of an Antarctic benthic community and quantify ecological trends during its recovery after iceberg scouring, analysing small scale photographic records $\left(1 \mathrm{~m}^{2}\right)$ from the Weddell Sea shelf. We first pro- vide quantitative data on changes in coverage, number of patches and number of taxa among different taxonomic benthic categories through recovery. Secondly, we describe faunal heterogeneity using an ordination technique and select 'structural taxa' for each stage, indicating their specific coverage, number of patches, and mean and maximum areas. Thirdly, we examine changes in growth-form patterns and their occupation of open space along the recovery gradient. Finally, we discuss our results by comparing the selected 'structural species' and relating their life-history traits in order to better understand the differences in distribution during the course of recovery. This publication is part of a larger study focused on recovery processes after iceberg disturbance (N. Teixidó et al. unpubl. data).

\section{MATERIALS AND METHODS}

Study area. Kapp Norvegia is located in the SE Weddell Sea (Fig. 1), where the continental shelf is relatively narrow (less than $90 \mathrm{~km}$ ) and occurs at depths of 300 to $500 \mathrm{~m}$ (Carmack \& Foster 1977, Elverhøi \& Roaldset 1983). Seasonal sea ice covers the continental shelf and extends beyond the continental break (Tréguer \& Jacques 1992), but coastal polynyas of varying size may occur (Hempel 1985). Water tem-

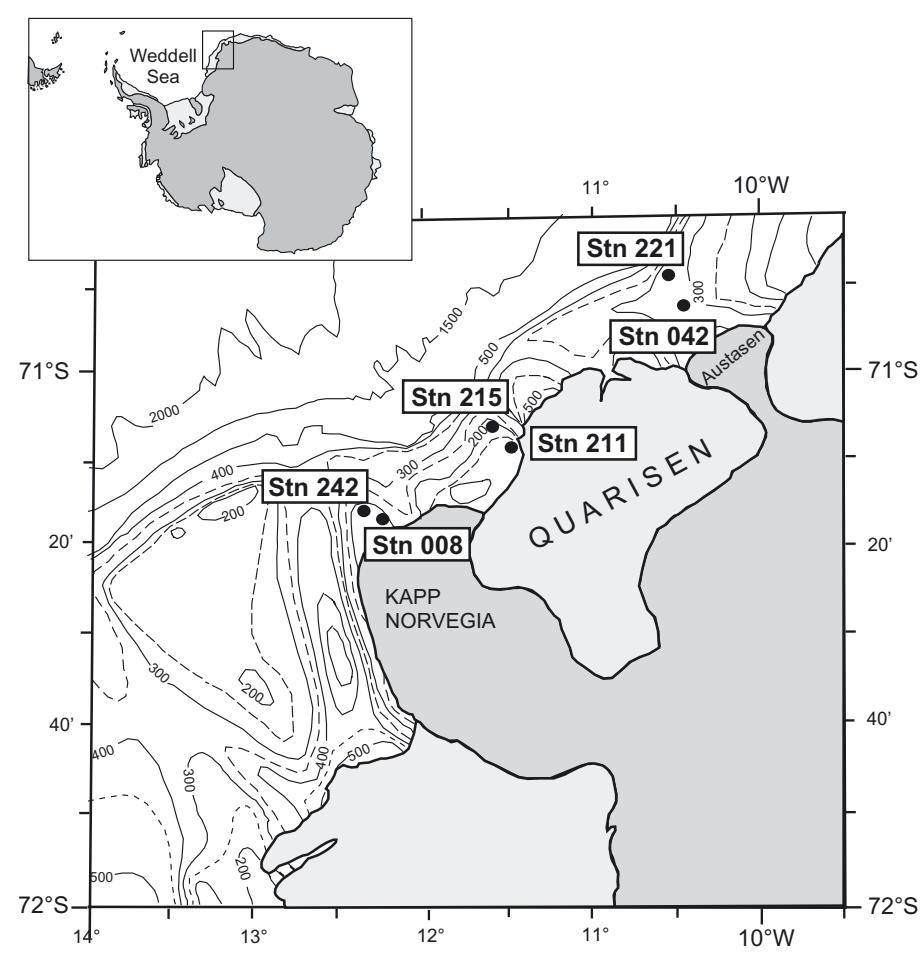

Fig. 1. Photographic stations in the SE Weddell Sea, Antarctica (subsection of chart AWI BCWS 553) 
perature close to the seafloor is low and very constant throughout the year, ranging from -1.3 to $-2.0^{\circ} \mathrm{C}$ (Fahrbach et al. 1992). There is a marked summertime peak in primary production (Nelson et al. 1989, Gleitz et al. 1994, Park et al. 1999), reflected by the organic matter flux from surface waters to the seabed (Bathmann et al. 1991, Gleitz et al. 1994). Hydrodynamics affect food availability (e.g. resuspension, lateral transport) and determine sediment characteristics such as grain size and composition, which are of ecological relevance for benthic communities (Dunbar et al. 1985, Gutt 2000).

Benthic communities and photosampling. The benthic communities inhabiting areas affected by iceberg scouring exhibit a wide range of complexity: from areas almost devoid of any fauna through stages with few abundant species to highly complex communities characterised by a relatively high species richness and extremely high biomass (Gutt et al. 1996, Gerdes et al. 2003). We identified 3 stages of recolonisation (from younger to older: R0, R1, R2) and an undisturbed assemblage (UD), classified previously by Gutt \& Starmans (2001). Definitions of these stages were based on qualitative criteria differing in faunistic composition, categorical abundance and features of the seabed relief (e.g. drastic rifts in the bottom scoured by icebergs). In the Weddell Sea, early successional stages are considered precursors toward the late slow-growing hexactinellid sponge stage (Dayton 1979, Gatti 2002), assuming that many decades or even centuries may be necessary to return to such a mature community after disturbance. However, no quantitative studies have been carried out to characterise this pattern.

Photographic records of the seafloor were obtained during the expeditions ANT XIII/3 and ANT XV/3 on board R/V 'Polarstern' during the austral summers of 1996 and 1998 (Arntz \& Gutt 1997, 1999), within the Ecology of the Antarctic Sea Ice Zone programme (EASIZ) of the Scientific Committee on Antarctic Research (SCAR). A 70 mm underwater camera (Photosea 70) with 2 oblique strobe lights (Photosea 3000 SX) was used at 6 stations (depth range: 117 to $265 \mathrm{~m}$ ) (Fig. 1). At each station, sequences of 80 vertical colour slides (Kodak Ektachrome 64), each covering approximately $1 \mathrm{~m}^{2}$ of the seabed, were taken at evenly spaced time intervals along a transect. The distance between consecutive photographs was close to $10 \mathrm{~m}$. The optical resolution was around $0.3 \mathrm{~mm}$. Seven photographs were analysed and processed at each stage (from R0 to UD), wherever these occurred (Table 1). The number of pho- tographic samples was 21 for R0, 28 for R1, 21 for R2 and 42 for the UD assemblage. Each sample was considered a replicate for the corresponding stage. In total, an area representing $112 \mathrm{~m}^{2}$ of the seafloor was analysed.

Image analysis. Each photograph was projected on an inverse slide projector and all distinguishable patch outlines were traced onto an acetate sheet at a map scale of 1:5. The drawings were scanned (100 dpi) and imported into the ArcView 3.2 (C ESRI) geographical information system (GIS) where they were spatially referenced. ArcView routine procedures were used to label all the patches. The result of a GIS process was an image related to a database table, which contained information on area, perimeter and a taxa identifier. Each individual patch was assigned to different categories (e.g. species, cluster of species) and its information was measured for each photograph. Areas of uncovered substrate were also reported.

Identification. Mega-epibenthic sessile organisms, approximately $>0.5 \mathrm{~cm}$ in body size diameter, were identified to the lowest possible taxonomic level by photo-interpreting following Thompson \& Murray (1880-1889), Discovery Committee Colonial Office (1929-1980), Monniot \& Monniot (1983), Sieg \& Wägele (1990) and Hayward (1995). In the present study, we did not analyse mobile organisms, which also appeared as first immigrants, such as fish and some echinoderms (Gutt et al. 1996, Brenner et al. 2001).

We recognised a total of 118 sessile organisms and sediment cover categories (see Appendix 1). These included species/genus (106), phylum (5), 'complex' (7) and substratum (5). Within the species/genus category, some unidentified sponges (e.g. 'Yellow branches') were named according to Barthel \& Gutt (1992). Irregular masses composed of matrices of bryozoans, demosponges, and gorgonians of small size and similar filamentous morphology were assigned to one of the 7 'complex' cover classes.

Table 1. List of the 6 photographic stations in the SE Weddell Sea. Seven photographs were analysed along the 3 stages of recolonisation (from younger to older: R0, R1, R2) and the undisturbed assemblage (UD), wherever these occurred

\begin{tabular}{|lccccc|}
\hline Stn & $\begin{array}{c}\text { Depth } \\
(\mathrm{m})\end{array}$ & R0 & \multicolumn{4}{c|}{ Rdentified assemblages } \\
& & & R2 & UD \\
\hline 008 & $171-173$ & 7 & 7 & 7 & 7 \\
042 & $260-243$ & - & - & - & 7 \\
211 & 117 & - & 7 & - & 7 \\
215 & $167-154$ & 7 & - & 7 & 7 \\
221 & $261-270$ & 7 & 7 & - & 7 \\
242 & $159-158$ & - & 7 & 7 & 7 \\
No. of photos & & 21 & 28 & 21 & 42 \\
\hline
\end{tabular}


Data analysis. Benthic composition, coverage and number of patches: Within each stage, we calculated cover area (CA), number of patches (NP) and number of taxa (NT) among different taxonomic benthic categories. The amount of substrate was also reported for all the stages. CA and NP were expressed as the mean percentage cover and the mean number of patches per photograph, respectively. NT represented the total number of taxa found among the different taxonomic categories.

Community analysis and 'structural taxa': Taxonomic composition among photographic 'samples' was compared using the Bray-Curtis similarity coefficient (Bray \& Curtis 1957) of 4th-root transformed sessile benthic coverage. Benthic taxa with less than $2 \%$ of the total coverage were excluded to minimise the bias caused by rare taxa (Field et al. 1982). Non-metric multidimensional scaling (MDS) (Kruskal \& Wish 1978) was applied to the similarity matrix to order the photographic samples in a 2-dimensional plane. Low stress values $(<0.20)$ indicate a good representation and little distortion of samples in the 2-dimensional ordination plot (Clarke 1993). The analysis was also carried out with number of patches (NP) (4th-root transformed and considering the taxa present in 3 or more samples). The MDS ordination plot was essentially the same as in the former MDS for benthic coverage and for this reason is not presented here.

In this study, 'structural taxa' refer to the selected representative taxa for each stage. These characteristic taxa were determined with the similarity percentage procedure (SIMPER) (Clarke \& Warwick 1994). The analysis indicates the contribution of each species to the average similarity within a group. The more present and abundant a species is within a group, the more it will contribute to the intra-group similarity (Clarke 1993). As in MDS analysis, the coverage of benthic fauna was 4th-root transformed and taxa occurring in $<2 \%$ of the samples were omitted. Moreover, complex categories (7) and taxa identified at coarse taxonomic level (5) (see Appendix 1) were also excluded. Both MDS and SIMPER analyses were performed using PRIMER software (version 5) (Clarke \& Gorley 2001).

Finally, for each 'structural taxa', we reported CA, NP and mean patch area (MPA). CA and NP were calculated as previously mentioned. MPA was reported as the area of patches divided by the number of patches within each structural taxa. We also calculated the mean maximum area (MMA) by averaging the maximum areas of the 5 largest specimens at each successional stage. For better interpretation, we pooled these 5 values of each 'structural taxa' per main taxonomic group. One-way ANOVA was applied to test significant differences in maximum area among stages using the STATISTICA program (version 5.5, StatSoft). A double square root transformation was used to achieve normality and equal variance. Post hoc multiple comparisons of means were performed using Tukey's test (Sokal \& Rohlf 1981).

Growth form. The 118 sessile benthic cover categories were grouped into 4 growth forms in order to search for patterns of CA, NP and MPA through recovery. The growth forms considered were bush, sheet, tree and mound (see Table 2 for a description of each growth form). This classification was based on previous studies on clonal organisms in coral reefs (e.g. review by Jackson 1979, Connell \& Keough 1985). This categorisation takes into account relevant ecological strategies followed by benthic species in occupying space on rocky benthic habitats. The benthos in the Weddell Sea locally presents different stratum levels of organisms. Therefore it should be considered that the nature of the images (vertical to the seabed) could reduce the contribution of the basal stratum to the total coverage because other organisms may cover it. In addition, the bryozoan Camptoplites tricornis exhibited a runner growth form but it was the only species of this category; for that reason it was classified into the bush form, which appears as the most similar.

In this case, CA referred only to the sessile benthic organisms and sediment coverage was not considered. Data on CA, NP and MPA were calculated as previously mentioned but referring to the growth-form category. Kruskal-Wallis nonparametric analysis was used to test for differences in growth-form patterns among successional stages. Post hoc comparisons of ranks were performed using the Nemenyi test (Sachs 1984). We used nonparametric analysis because most

Table 2. Description of growth forms used in this study (from Jackson 1979, Connell \& Keough 1985)

\begin{tabular}{|c|c|}
\hline $\begin{array}{l}\text { Growth } \\
\text { form }\end{array}$ & Description \\
\hline Bush & $\begin{array}{l}\text { Upright forms branching from the base, } \\
\text { mainly flexible hydrozoans and bryozoans; } \\
\text { with a restricted area of attachment to the } \\
\text { substratum }\end{array}$ \\
\hline Sheet & $\begin{array}{l}\text { Encrusting species of sponges, bryozoans, } \\
\text { sabellids and ascidians growing as } 2 \text {-dimen- } \\
\text { sional sheets; more or less completely } \\
\text { attached to the substratum }\end{array}$ \\
\hline Tree & $\begin{array}{l}\text { Erect species of sponges, gorgonians, } \\
\text { bryozoans and ascidians, more or less } \\
\text { branched; with a restricted area of attach- } \\
\text { ment to the substratum }\end{array}$ \\
\hline Mound & $\begin{array}{l}\text { Massive species of sponges, anemones, } \\
\text { ascidians and pterobranchs with extensive } \\
\text { vertical and lateral growth; attached to the } \\
\text { substratum along basal area }\end{array}$ \\
\hline
\end{tabular}


of the data did not follow normality after different transformations. The Kruskal-Wallis test was computed using the STATISTICA program (version 5.5, StatSoft).

\section{RESULTS}

\section{Patterns of benthic composition, coverage and abundance}

Uncovered sediment characterised R0 with a mean value of $98.2 \%$ and few benthic taxa (Fig. 2). Bryozoans, polychaetes, gorgonians and ascidians contributed to the low benthic coverage of the seafloor with a mean value of $0.5,0.5,0.3$ and $0.1 \%$, respectively, whereas there were more patches of polychaetes (NP) (8 patches $\mathrm{m}^{-2}$ ) than bryozoans $\left(3\right.$ patches $\mathrm{m}^{-2}$ ). However, most taxa were bryozoans (NT) (12). Similarly, R1 exhibited a high coverage of sediment (91\%) (Fig. 2). Bryozoans, gorgonians, 'complex category', demosponges, polychaetes and ascidians showed 3.8, 1.5, $1.4,0.5,0.5$ and $0.4 \%$ of cover area (CA), respectively. Mean values of NP ranged from 38 patches $\mathrm{m}^{-2}$ for bryozoans through 11 patches $\mathrm{m}^{-2}$ for gorgonians to 2 patches $\mathrm{m}^{-2}$ for ascidians. The highest mean of CA $(70.5 \%)$ and NP (173 patches $\left.\mathrm{m}^{-2}\right)$ occurred in R2, whereas uncovered sediment showed the lowest value ( 29.5\%) (Fig. 2). CA values fluctuated from 36\% ('complex category') to $5 \%$ (demosponge) and $0.8 \%$ (hexactinellids), whereas bryozoans with $24 \%$ of CA exhibited the highest mean value of NP (76 patches $\mathrm{m}^{-2}$ ) and NT (32 taxa). Demosponges (35 patches $\mathrm{m}^{-2}$, 18 taxa) and ascidians (32 patches $\mathrm{m}^{-2}, 10$ taxa) also showed a high NP and NT. In UD, the space covered by benthic organisms was $53 \pm 6.5 \%$ (SD) (Fig. 2) where 'complex category', demosponges and bryozoans accounted for $42 \pm 2.7 \%$ (SD) of benthic coverage.
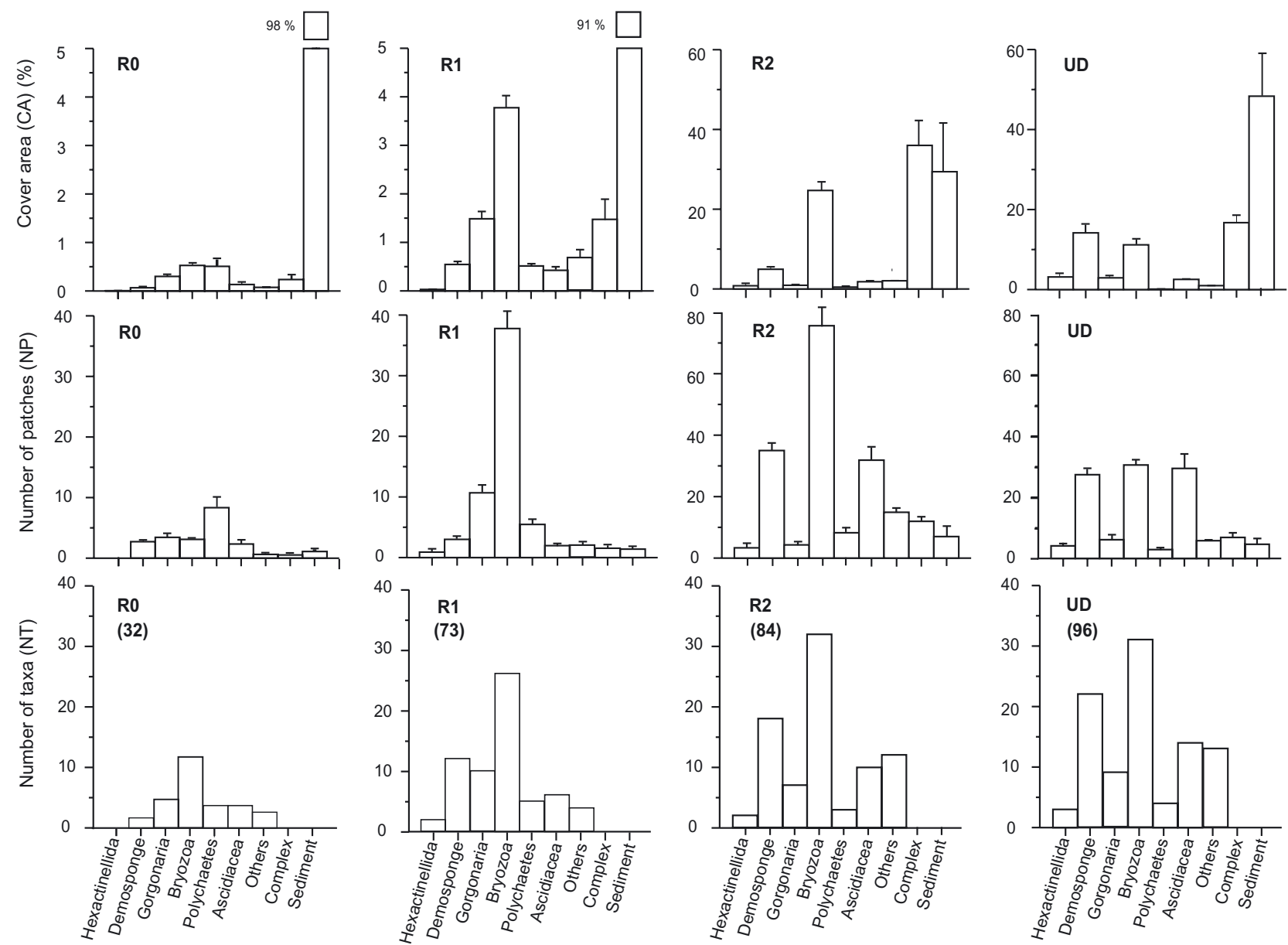

Fig. 2. Cover area $(\mathrm{CA})($ mean $\pm \mathrm{SD})$, number of patches (NP) (mean $\pm \mathrm{SD}$ ) and total number of taxa (NT) among different taxonomic categories through recovery stages. $\mathrm{n}=14$ for R0, 28 for R1, 21 for R2, and 42 for UD. Others-in R0 and R1: Hydrozoa $(0.07$ and $0.6 \%)$; in R2: Hydrozoa, Actinaria, Holothuroidea and Pterobranchia $(0.8 \%)$; in UD: Hydrozoa, Actinaria, Holothuroidea and Pterobranchia $(0.8 \%)$. Numbers in parentheses indicate the total number of taxa per stage 
Bryozoans, demosponges and ascidians exhibited high NP $\left(31,27\right.$ and 29 patches $\mathrm{m}^{-2}$, respectively) and NT (31, 22 and 14 taxa, respectively). Hexactinellids showed comparatively moderate values for both CA $(3 \%)$ and NP (4 patches $\left.\mathrm{m}^{-2}\right)$, and low NT (3 taxa).

\section{Community analysis and 'structural taxa'}

The MDS ordination showed a gradual change in the benthic composition among samples from different recovery stages (Fig. 3). Faunal dissimilarity was higher in the early stages (R0 and R1) with larger dispersion of samples than in the later stages. However, there was an overlap of samples mainly between R0-R1 and R2-UD indicating a similarity in benthic taxa through the recovery stages. Seven samples were grouped apart within the set of the UD. These samples belonged to Stn 211 dominated by Cinachyra barbata (demosponge) and hexactinellids.

'Structural taxa' that characterised the different recovery stages are shown in Table 3 . The patchy distribution of most of the fauna is evident by comparing the mean value for both CA and NP, and their extreme values (Table 3). The structural taxa in R0 were the sabellid polychaetes (Myxicola cf. sulcata and Perkinsiana spp.), the solitary ascidian Molgula pedunculata, the lollypop-like sponge Stylocordyla borealis and the soft bryozoan Camptoplites lewaldi. In general, these taxa covered the space with small patches $\left(<15 \mathrm{~cm}^{2}\right)$. Within R1, colonies of gorgonians (Primnoisis antarctica and Primnoella spp.), soft and rigid bryozoans ( $C$. lewaldi, Alcyonidum 'latifolium' and Cellarinella spp., Cellarinella nodulata, Smittina antarctica and Systenopora contracta), the sabellid polychaete $M$. cf. sulcata,

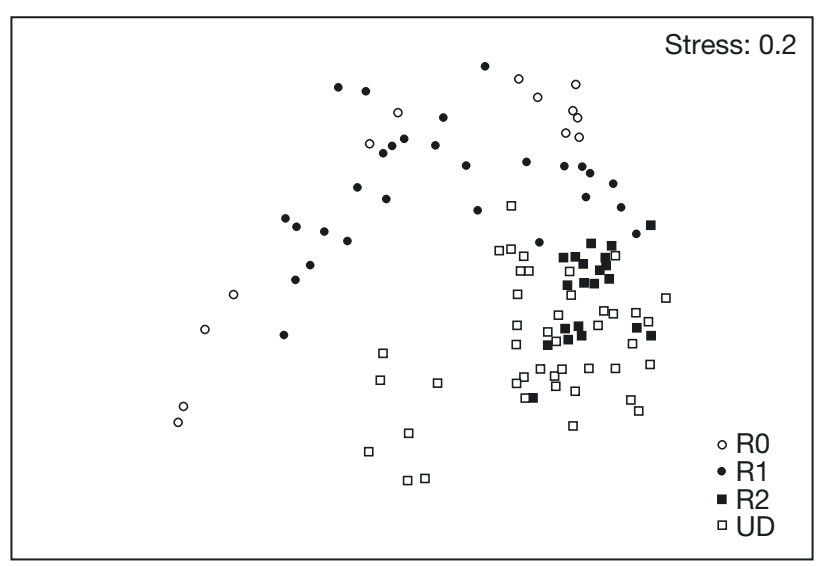

Fig. 3. MDS diagram of photographic sample similarity according to benthic taxa composition through the recovery stages. Only 13 of the 21 photographic samples in R0 are represented due to the absence of sessile organisms in the 8 missing samples. Note that 7 samples from UD are grouped apart and the sponge $S$. borealis were the most representative taxa. The rigid bryozoan Cellarinella spp. showed a maximum of $13 \%$ in CA, 51 patches $\mathrm{m}^{-2}$ and a large area up to $248 \mathrm{~cm}^{2}$ (Table 3). Benthic fauna that characterised the later stages (R2 and UD) were more numerous and varied. Within R2, bryozoans, demosponges, gorgonians, hexactinellids, polychaetes and compound ascidians were important. Different soft and rigid taxa of bryozoans were the most representative, such as Cellarinella spp. with a mean cover value of 13 $\pm 2.7 \%$ (SE) and $31 \pm 5.8$ (SE) patches $\mathrm{m}^{-2}$, and exhibiting a maximum cover value of $35 \%$ (Table 3 ). The 4 representative demosponges represented $\sim 10 \%$ of the total benthic coverage, of which the massive-round demosponge Cinachyra barbata showed locally high CA $(23 \%)$, NP $\left(35\right.$ patches $\left.\mathrm{m}^{-2}\right)$ and MPA $\left(109 \mathrm{~cm}^{2}\right)$. Many 'structural taxa' present in R2 were also important in UD, where the selected sponges (both hexactinellids and demosponges) reached approximately $30 \%$ of the total benthic coverage. The vase-shaped hexactinnellid Rossella nuda/Scolymastra joubini exhibited moderate values of mean coverage, $2 \pm 0.4 \%$ (SE), with a mean abundance of $2 \pm 0.4$ (SE) patches $\mathrm{m}^{-2}$ and a patch area of $83 \pm 16.0 \mathrm{~cm}^{2}(\mathrm{SE})$, but show extremely high values in coverage (13\%), NP (11 patches $\mathrm{m}^{-2}$ ) and the largest area $\left(666 \mathrm{~cm}^{2}\right)$ (Table 3).

Fig. 4 represents the mean maximum area (MMA) distribution of each 'structural taxa' grouped in the corresponding taxonomic groups through recovery. Overall, it is evident that the MMA for each group increased as recovery proceeded. The biggest colonies were the hexactinnellids $\left(315 \mathrm{~cm}^{2}\right)$, whereas the polychaetes showed the lowest value $\left(18 \mathrm{~cm}^{2}\right)$ in UD. The MMA of hexactinnellids, demosponges and bryozoans differed significantly between the first (R0 and R1) and the later stages (R2 and UD) $(F=18.57, F=18.07, F=$ 39.75, respectively and $p<0.0001)$ (Fig. 4). Polychaetes showed the highest value $\left(22 \mathrm{~cm}^{2}\right)$ in $\mathrm{R} 1$, which differed significantly from R0 $(F=6.1, \mathrm{p}<0.0001)$. Ascidians differed significantly between R0 $\left(5.8 \mathrm{~cm}^{2}\right)$ and the rest of the stages $(F=8.4, p<0.0001)$. Gorgonians had an intermediate value $\left(98 \mathrm{~cm}^{2}\right)$ in UD, which differed significantly between the first stages (R0 and R1) $(F=4.9, \mathrm{p}<0.001)$ but not with R2 $(\mathrm{p}>0.05)$.

\section{Changes in growth-form categories of CA, NP and MPA}

There were large differences in cover area (CA), number of patches (NP) and mean patch area (MPA) of growth forms among the recovery stages (Fig. 5). Overall, bush growth form (hydrozoans and bryozoans) was the most abundant category in R0 contributing $28 \pm 6.3 \%$ (SE) to the coverage, tree-like 
Table 3. Representative benthic organisms accounting for $75 \%$ of the average similarity within each stage. Taxa are ordered by decreasing contribution. Data include means \pm SE of cover area (CA), number of patches (NP) and mean patch area (MPA). Maximum and minimum values are shown in parentheses. Each photograph $\sim 1 \mathrm{~m}^{2} .{ }^{*}$ Cover category groups-ASC: Ascidiacea; BRY: Bryozoa; COM: Complex; DEM: Demospongiae; GOR: Gorgonaria; HEX: Hexactinellida; POL: Polychaeta. ${ }^{* *}$ Growth forms - B: bush; S: sheet; T: tree; M: mound

\begin{tabular}{|c|c|c|c|c|c|c|}
\hline Stage & Structural taxon & Group* & Form ${ }^{* *}$ & CA $(\%)$ & NP & MPA $\left(\mathrm{cm}^{2}\right)$ \\
\hline $\begin{array}{l}\text { R0 } \\
\mathrm{n}=21\end{array}$ & $\begin{array}{l}\text { Myxicola cf. sulcata } \\
\text { Perkinsiana spp. } \\
\text { Molgula pedunculata } \\
\text { Stylocordyla borealis } \\
\text { Camptoplites lewaldi }\end{array}$ & $\begin{array}{l}\text { POL } \\
\text { POL } \\
\text { ASC } \\
\text { DEM } \\
\text { BRY }\end{array}$ & $\begin{array}{l}\mathrm{S} \\
\mathrm{S} \\
\mathrm{T} \\
\mathrm{T} \\
\mathrm{B}\end{array}$ & $\begin{array}{l}0.34 \pm 0.16(2.85-0) \\
0.07 \pm 0.02(0.35-0 \\
0.12 \pm 0.05(0.6-0) \\
0.03 \pm 0.01(0.14-0) \\
0.11 \pm 0.06(1.2-0)\end{array}$ & $\begin{array}{l}4.9 \pm 2.0(31-0) \\
1.5 \pm 0.5(9-0) \\
1.5 \pm 0.6(9-0) \\
1.9 \pm 0.6(10-0) \\
0.6 \pm 0.3(6-0)\end{array}$ & $\begin{array}{r}6.3 \pm 0.4(20.3-1.1) \\
4.5 \pm 0.4(10.5-1.7) \\
6.7 \pm 0.4(12.1-0.8) \\
1.2 \pm 0.18(4.2-0.7) \\
14.9 \pm 3.6(19.1-4.9)\end{array}$ \\
\hline $\begin{array}{l}\text { R1 } \\
\mathrm{n}=28\end{array}$ & $\begin{array}{l}\text { Primnoisis antarctica } \\
\text { Primnoella spp. } \\
\text { Cellarinella spp. } \\
\text { Myxicola cf. sulcata } \\
\text { Alcyonidium 'latifolium' } \\
\text { Smittina antarctica } \\
\text { Systenopora contracta } \\
\text { Camptoplites lewaldi } \\
\text { Cellarinella nodulata } \\
\text { Stylocordyla borealis }\end{array}$ & $\begin{array}{l}\text { GOR } \\
\text { GOR } \\
\text { BRY } \\
\text { POL } \\
\text { BRY } \\
\text { BRY } \\
\text { BRY } \\
\text { BRY } \\
\text { BRY } \\
\text { DEM }\end{array}$ & $\begin{array}{l}\mathrm{T} \\
\mathrm{T} \\
\mathrm{T} \\
\mathrm{S} \\
\mathrm{S} \\
\mathrm{T} \\
\mathrm{T} \\
\mathrm{S} \\
\mathrm{T} \\
\mathrm{T}\end{array}$ & $\begin{array}{l}0.46 \pm 0.15(3.0-0) \\
0.29 \pm 0.11(3.0-0) \\
1.48 \pm 0.62(13.0-0) \\
0.22 \pm 0.06(1.3-0) \\
0.20 \pm 0.1(1.9-0) \\
0.11 \pm 0.03(0.8-0) \\
0.20 \pm 0.07(1.3-0) \\
0.13 \pm 0.04(0.7-0) \\
0.15 \pm 0.06(1.5-0) \\
0.02 \pm 0.01(0.13-0)\end{array}$ & $\begin{aligned} & 3.5 \pm 1.2(30-0) \\
& 3.6 \pm 0.9(19-0) \pm 2.7(51-0) \\
& 9.1 \pm 2.7(11-0) \\
& 1.7 \pm 0.5(11-0) \\
& 16.9 \pm 7.6(153-0) \\
& 1.3 \pm 0.3(8-0) \\
& 1.3 \pm 0.3(7-0) \\
& 1.0 \pm 0.3(6-0) \\
& 2.2 \pm 0.7(20-0) \\
& 1.6 \pm 0.4(8-0)\end{aligned}$ & $\begin{aligned} 7.4 & \pm 0.7(25.7-0.6) \\
7.3 & \pm 0.9(22.7-0.5) \\
14.8 & \pm 1.7(248.7-0.1) \\
12.2 & \pm 1.1(34.4-0.9) \\
1.1 & \pm 0.04(6.3-0.2) \\
7.8 & \pm 1.4(47.1-0.9) \\
13.3 & \pm 3.3(92.8-0.6) \\
12.5 & \pm 2.1(47.9-1.5) \\
4.7 & \pm 1.1(53.5-0.1) \\
1.4 & \pm 0.2(7.4-0.8)\end{aligned}$ \\
\hline $\begin{array}{l}\mathbf{R} 2 \\
\mathrm{n}=21\end{array}$ & $\begin{array}{l}\text { Cellarinella spp. } \\
\text { Systenopora contracta } \\
\text { Synoicium adareanum } \\
\text { Cellarinella nodulata } \\
\text { 'Yellow branches' } \\
\text { Camptoplites tricornis } \\
\text { Cinachyra barbata } \\
\text { Hornea spp. } \\
\text { Stylocordyla borealis } \\
\text { Paracellaria wandeli } \\
\text { Notisis spp. } \\
\text { Notoplites spp. } \\
\text { Rossella racovitzae } \\
\text { Tedania tantula } \\
\text { Myxicola cf. sulcata } \\
\text { Polysyncraton trivolutum }\end{array}$ & $\begin{array}{l}\text { BRY } \\
\text { BRY } \\
\text { ASC } \\
\text { BRY } \\
\text { DEM } \\
\text { BRY } \\
\text { DEM } \\
\text { BRY } \\
\text { DEM } \\
\text { BRY } \\
\text { GOR } \\
\text { BRY } \\
\text { HEX } \\
\text { DEM } \\
\text { POL } \\
\text { ASC }\end{array}$ & $\begin{array}{c}\mathrm{T} \\
\mathrm{T} \\
\mathrm{M} \\
\mathrm{T} \\
\mathrm{T} \\
\mathrm{S} \\
\mathrm{M} \\
\mathrm{T} \\
\mathrm{T} \\
\mathrm{T} \\
\mathrm{B} \\
\mathrm{B} \\
\mathrm{M} \\
\mathrm{T} \\
\mathrm{S} \\
\mathrm{M}\end{array}$ & $\begin{aligned} 12.7 & \pm 2.7(35.1-0) \\
1.5 & \pm 0.4(8.6-0.02) \\
0.6 & \pm 0.2(3.6-0.02) \\
1.2 & \pm 0.4(7.9-0) \\
0.88 & \pm 0.2(3.7-0) \\
2.4 & \pm 0.9(18.8-0) \\
2.1 & \pm 1.0(22.6-0) \\
0.22 & \pm 0.06(1.1-0) \\
0.88 & \pm 0.24(3.7-0) \\
0.5 & \pm 0.1(1.6-0) \\
0.63 & \pm 0.2(4.8-0) \\
0.82 & \pm 0.25(3.8-0) \\
0.2 & \pm 0.06(1.1-0) \\
0.2 & \pm 0.06(1.2-0) \\
0.25 & \pm 0.09(1.7-0) \\
0.3 & \pm 0.11(1.9-0)\end{aligned}$ & $\begin{aligned} 30.8 & \pm 5.8(78-1) \\
9.1 & \pm 1.1(19-1) \\
7.6 & \pm 1.5(24-1) \\
11.8 & \pm 3.7(75-0) \\
7.2 & \pm 1.5(23-0) \\
1.8 & \pm 0.4(6-0) \\
4.5 & \pm 1.7(35-0) \\
2.5 & \pm 0.6(13-0) \\
9.8 & \pm 2.8(39-0) \\
2.1 & \pm 0.3(5-0) \\
3.0 & \pm 0.7(11-0) \\
1.4 & \pm 0.4(6-0) \\
2.1 & \pm 0.4(7-0) \\
8.8 & \pm 3.2(59-0) \\
4.6 & \pm 1.2(17-0) \\
9.3 & \pm 4.1(82-0)\end{aligned}$ & $\begin{aligned} 33.7 & \pm 2.7(681.9-0.1) \\
16.5 & \pm 4.5(184.6-0.2) \\
8.2 & \pm 1.2(163.6-0.2) \\
12.5 & \pm 1.6(183.2-0.1) \\
12.5 & \pm 1.2(81.3-1.0) \\
134 & \pm 36.2(520.1-0.2) \\
43.9 & \pm 6.5(109-0.9) \\
7.9 & \pm 0.9(41.8-0.8) \\
8.1 & \pm 1.1(55.8-0.9) \\
21.6 & \pm 4.3(119.7-0.5) \\
17.8 & \pm 5.8(66.6-0.1) \\
62.8 & \pm 13.3(301-3.8) \\
21.3 & \pm 13.8(648 .-0.9) \\
2.4 & \pm 0.4(57.2-0.1) \\
4.9 & \pm 0.5(19.7-0.8) \\
3.0 & \pm 2.8(20.8-0.5)\end{aligned}$ \\
\hline $\begin{array}{l}\text { UD } \\
\mathrm{n}=42\end{array}$ & $\begin{array}{l}\text { Cinachyra barbata } \\
\text { Rossella nuda/S. joubini } \\
\text { Polysyncraton trivolutum } \\
\text { Notisis spp. } \\
\text { Cellarinella spp. } \\
\text { Synoicium adareanum } \\
\text { 'Yellow branches' } \\
\text { Systenopora contracta } \\
\text { Rossella racovitzae } \\
\text { Cinachyra antarctica } \\
\text { Notoplites spp. } \\
\text { Cellarinella nodulata } \\
\text { Cellaria aurorae } \\
\text { Hornea spp. } \\
\text { Monosyringa longispina } \\
\text { Cellaria spp. } \\
\text { Reteporella spp. }\end{array}$ & $\begin{array}{l}\text { DEM } \\
\text { HEX } \\
\text { ASC } \\
\text { GOR } \\
\text { BRY } \\
\text { ASC } \\
\text { DEM } \\
\text { BRY } \\
\text { HEX } \\
\text { DEM } \\
\text { BRY } \\
\text { BRY } \\
\text { BRY } \\
\text { BRY } \\
\text { DEM } \\
\text { BRY } \\
\text { BRY }\end{array}$ & $\begin{array}{c}\mathrm{M} \\
\mathrm{M} \\
\mathrm{M} \\
\mathrm{B} \\
\mathrm{T} \\
\mathrm{M} \\
\mathrm{T} \\
\mathrm{T} \\
\mathrm{M} \\
\mathrm{M} \\
\mathrm{B} \\
\mathrm{T} \\
\mathrm{T} \\
\mathrm{T} \\
\mathrm{M} \\
\mathrm{B} \\
\mathrm{M}\end{array}$ & $\begin{aligned} 10.8 & \pm 2.2(45.0-0) \\
1.65 & \pm 0.4(12.6-0) \\
0.4 & \pm 0.09(3.2-0) \\
1.65 & \pm 0.5(18.5-0) \\
1.65 & \pm 0.5(18.5-0) \\
1.4 & \pm 0.3(8.23-0) \\
0.65 & \pm 0.15(3.5-0) \\
0.32 & \pm 0.1(2.9-0) \\
1.23 & \pm 0.5(14.2-0) \\
0.34 & \pm 0.1(2.5-0) \\
1.13 & \pm 0.4(15.4-0) \\
0.5 & \pm 0.1(4.4-0) \\
1.3 & \pm 0.4(1.6-0) \\
0.08 & \pm 0.01(0.4-0) \\
0.5 & \pm 0.16(4.5-0) \\
2.5 & \pm 0.9(24.1-0) \\
0.3 & \pm 0.09(2.3-0)\end{aligned}$ & $\begin{aligned} 27.4 & \pm 0.4(48-0) \\
1.8 & \pm 0.4(11-0) \\
8.3 & \pm 1.9(67-0) \\
2.9 & \pm 0.5(10-0) \\
6.9 & \pm 2.1(63-0) \\
16.2 & \pm 3.7(38-0) \\
5.0 & \pm 1.2(28-0) \\
3.5 & \pm 0.9(31-0) \\
1.4 & \pm 0.3(7-0) \\
1.2 & \pm 0.3(8-0) \\
0.7 & \pm 0.1(3-0) \\
4.5 & \pm 1.4(38-0) \\
1.0 & \pm 0.2(6-0) \\
1.3 & \pm 0.2(7-0) \\
0.6 & \pm 0.2(6-0) \\
0.7 & \pm 0.2(4-0 \\
1.2 & \pm 0.3(8-0)\end{aligned}$ & $\begin{aligned} 94.7 & \pm 5.1(364.5-3.3) \\
83.4 & \pm 16.0(665.9-5.8) \\
4.1 & \pm 0.3(69.1-0.8) \\
29.4 & \pm 4.1(252-0.2) \\
20.5 & \pm 2.9(580.2-0.1) \\
8.05 & \pm 0.4(66.2-1.3) \\
12.2 & \pm 1.5(175.3-1.1) \\
8.5 & \pm 1.6(193.5-0.1) \\
16.9 & \pm 6.5(368-2.7) \\
25.1 & \pm 2.8(95.7-4.5) \\
89.2 & \pm 15.4(374-9.4) \\
9.4 & \pm 1.2(133.1-0.4) \\
72.4 & \pm 13.0(284-1.8) \\
5.7 & \pm 0.7(20.9-0.5) \\
67.8 & \pm 12.3(267-4.31) \\
131.0 & \pm 35.4(957-2.9) \\
24.7 & \pm 3.9(111.5-0.9)\end{aligned}$ \\
\hline
\end{tabular}

organisms (demosponges, gorgonians and ascidians) dominated in R1 $(47 \pm 3.8 \%, \mathrm{SE})$ and R2 (57 $\pm 5.2 \%$, $\mathrm{SE})$, whereas mound-like organisms (hexactinellids, demosponges, actinians and ascidians) characterised the UD stage, reaching $39 \pm 4.5 \%$ (SE) of the coverage. In contrast, sheet growth forms (demosponges, sabellids and ascidians) showed a discrete coverage in the early stages, which decreased significantly in the UD. In general, the first stages (R0 and R1) showed small and few patches, in contrast to NP and MPA of the tree category in R1 that showed higher values $\left(30 \pm 4.3\right.$ patches $\mathrm{m}^{-2}$ and $13 \pm 0.9 \mathrm{~cm}^{2}, \mathrm{SE}$, respectively) (Fig. 5). In R2, this growth form also showed a significantly high number of patches (96 \pm 

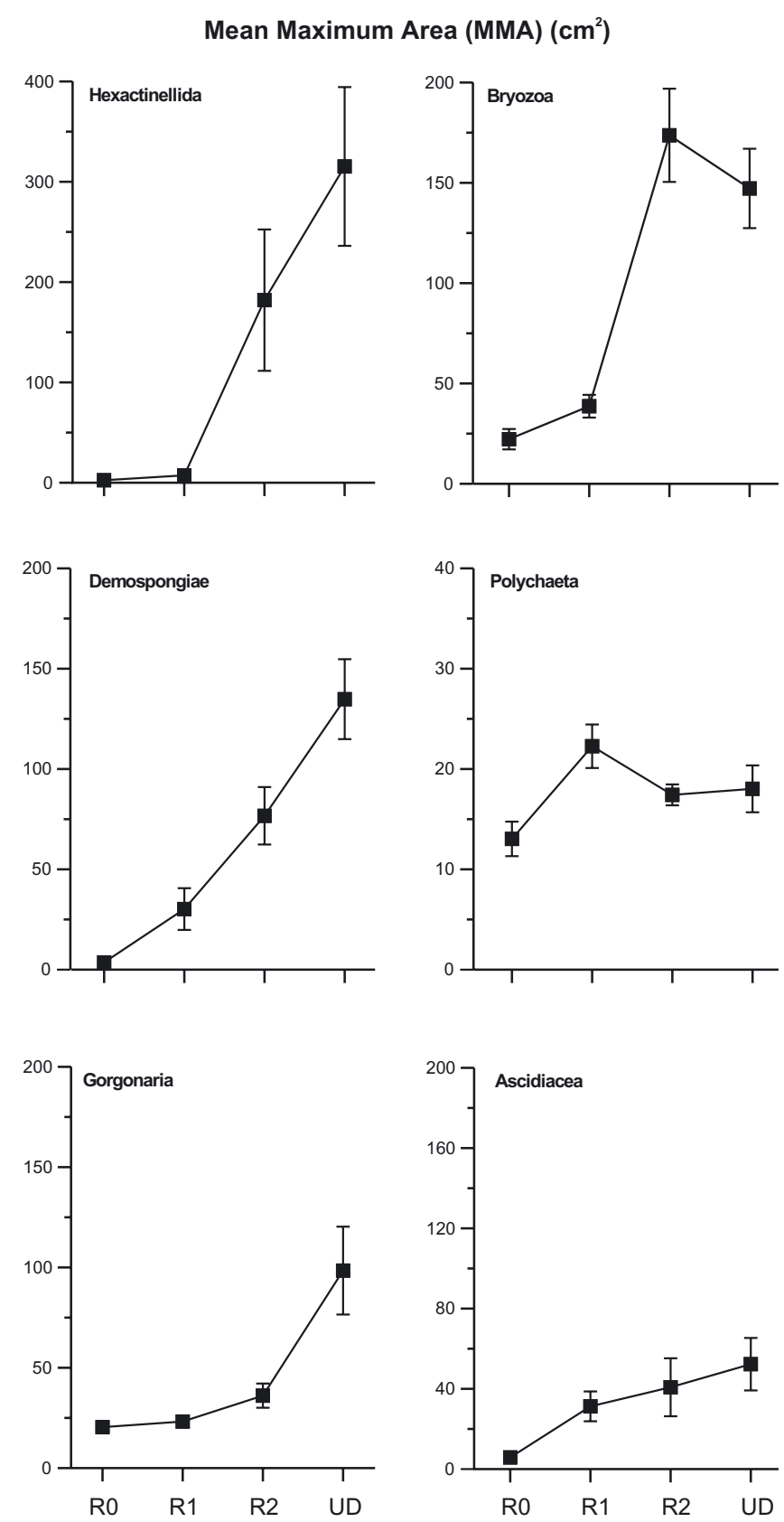

Fig. 4. Mean maximum area (MMA) distribution of the taxonomic groups through recovery. Data are means $\pm \mathrm{SE}$ of maximum areas of the largest specimens $(n=5)$ of each 'structural taxa'. It includes mean \pm SE. Hexactinellida (2 taxa), Demospongiae (6 taxa), Gorgonaria (3 taxa), Bryozoa (13 taxa), Polychaeta (2 taxa) and Ascidiacea (3 taxa)

9.9 patches $\left.\mathrm{m}^{-2}, \mathrm{SE}\right)$ with intermediate area $(37 \pm$ $\left.4.3 \mathrm{~cm}^{2}, \mathrm{SE}\right)$. In R2 and UD, large $\left(\sim 96 \mathrm{~cm}^{2}\right.$ for bush) and intermediate area $\left(\sim 18 \mathrm{~cm}^{2}\right.$ for sheet) and a moderate number of patches covered the seafloor. Moundlike forms also characterised UD with intermediate area $\left(36 \pm 1.7 \mathrm{~cm}^{2}, \mathrm{SE}\right)$ and number of patches $(47 \pm$ 5.2 patches $\left.\mathrm{m}^{-2}, \mathrm{SE}\right)$.

\section{Life-history traits}

In Table 4, we compile information on morphology, main reproduction modus, dispersal abilities of offspring, growth and estimated age for the 29 'structural' taxa. Furthermore, we provide information on 3 species (Homaxinella spp., Melicerita obliqua, and Primnoa resedaeformis) that were not selected in this study as representative, but their life-history traits are well documented and considered important for the discussion.

\section{DISCUSSION}

\section{Patterns of benthic composition, coverage, number of patches and area}

Iceberg scouring of Antarctic benthos can occur over large distances (several $\mathrm{km}$ ) creating a mosaic of habitat heterogeneity with sharp differences within a few metres (Gutt \& Piepenburg 2003). Both small- (this study) and large-scale spatial and temporal studies can greatly contribute to a better assessment of the response of Antarctic benthic communities to iceberg disturbance. In the high-latitude Antarctic benthos, there have been few ecological studies based on the temporal trajectory of succession due to a lack of continuity in sampling and great difficulties in performing in situ experiments (Arntz et al. 1994). Within these restrictions, this study provides new insights to better understand the structure and organisation through recovery in Antarctic communities.

The results showed that benthic composition was markedly different and provided evidence of community recovery through an increase of coverage, taxa, and number and area of patches along the recovery stages (Figs. $2 \& 4$ ). Furthermore, we found that a group of 'structural taxa' characterised each stage well (Table 3). These general patterns were reported in other marine communities studying different spatial and temporal scales (Dayton 1971, Connell et al. 1997, McCook \& Chapman 1997, Airoldi 2000).

We found that the first recovery stages (R0 and R1) were characterised by a low percentage of benthos coverage (CA) and a low number of taxa (NT) (Fig. 2). Few and small patches, mainly of bryozoans, polychaetes and ascidians, barely covered the sediment (Fig. 2, Table 3). The advanced stage (R2) exhibited the highest coverage and number of patches (NP) (Fig. 2). Bryozoans were important in CA, NP and NT, whereas demosponges and ascidians exhibited a relatively high NP and NT. The 'complex categories' composed the basal substrata of the benthos with a coverage of $36 \%$ for R2 and $16.7 \%$ for UD. This latter stage was characterised by an interme- 
diate coverage of bryozoans, demosponges, ascidians, gorgonians and hexactinellids.

In our results, the 'structural taxa' showed a net increase of area along recovery (Table 3, Fig. 4). This increase of area among the different taxa occurred despite epizoism, partial mortality of colonies and colony fission processes, which are common in benthic clonal invertebrates (Hughes \& Jackson 1980). These processes make age estimation based on area mea- surements difficult, thus the evaluation of timing after disturbance. Despite this, our results suggest that as time without disturbance passes, the benthic fauna gets larger and supposedly older. In this sense, it is interesting to note that big specimens of hexactinellids found in UD (approximately $30 \mathrm{~cm}$ in diameter) (Table 3, Fig. 4) were much smaller in comparison to giant sizes described below $50 \mathrm{~m}$ in the Ross Sea $(1.8 \mathrm{~m}$ tall with a diameter of $1.3 \mathrm{~m}$ ) (Dayton 1979). It remains
Cover area (CA) $(\%)$
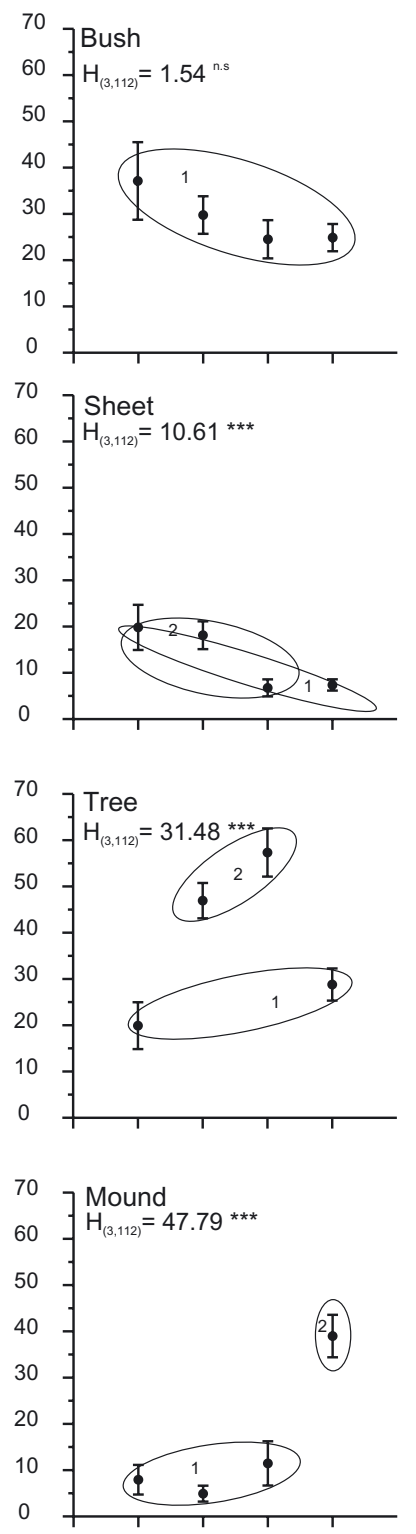

R0 R1 R2 UD
Number patches (NP)
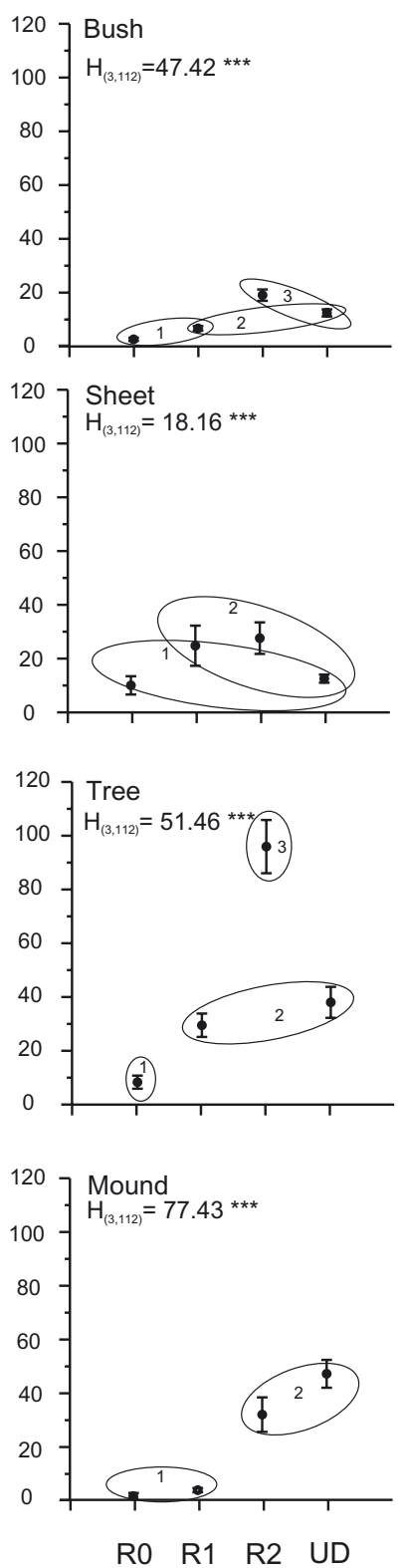

Mean patch area (MPA)

$\left(\mathrm{cm}^{2}\right)$

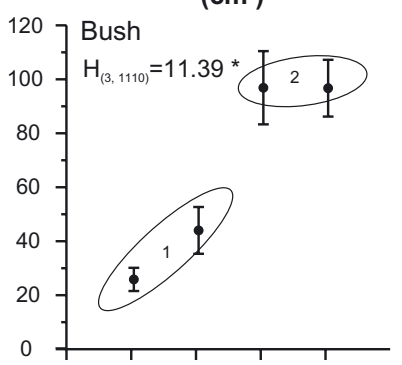

120 Sheet
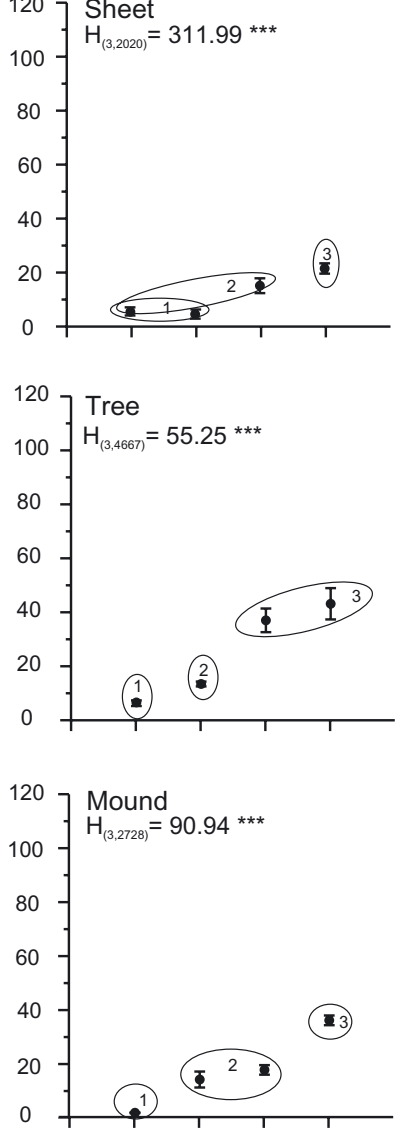

R0 R1 R2 UD

Fig. 5. Cover area (CA), number of patches (NP) and mean patch area (MPA) of growth form categories through recovery. Homogeneous groups are enclosed within a circle according to Nemenyi post hoc multiple comparisons. Data are means \pm SE. See Table 2 for growth form descriptions. Note that the sum of different growth form categories exhibits $\sim 85 \%$ of cover area in R0 due to the absence of sessile benthic fauna in some photographs. $H$ is the Kruskal-Wallis statistic; numbers in parentheses are degrees of freedom. n.s. = not significant; ${ }^{*} \mathrm{p}<0.05_{i}{ }^{* \star *} \mathrm{p}<0.001$ 
unclear whether the hexactinellids of the Weddell Sea reach the size of their counterparts in the Ross Sea, although Gutt (2000) suggested that these sponges are protected from iceberg scouring in the shallow habitat of McMurdo Sound enabling them to grow during longer periods and thus attain greater sizes.
After disturbance, variable successional pathways create new species combinations and interactions (Connell \& Slatyer 1977, Pickett \& White 1985, McCook 1994). Gutt (2000) found that there is no specific pattern of species replacement during succession in Antarctic benthic communities at larger spatial

Table 4. Life-history traits of the representative taxa (SIMPER analysis). They are ordered from early to late recolonisation stages. ${ }^{*},{ }^{* *}$ See Table 3 for abbreviations referring to taxonomic groups and growth forms. nd = not determined

\begin{tabular}{|c|c|c|c|c|}
\hline Taxon & Group* & Form ${ }^{* *}$ & Stage & Morphological description \\
\hline Perkinsiana spp. & POL & $\mathrm{S}$ & R0 & Sheet-like form \\
\hline Molgula pedunculata & ASC & $\mathrm{T}$ & R0 & Upright, stalked, solitary \\
\hline Stylocordyla borealis & DEM & $\mathrm{T}$ & $\mathrm{R} 0, \mathrm{R} 1, \mathrm{R} 2$ & Upright, stalked with spherical or oblong head \\
\hline Camptoplites lewaldi & BRY & $\mathrm{B}$ & R0, R1 & Flexible, open colony form \\
\hline Primnoisis antarctica & GOR & $\mathrm{T}$ & $\mathrm{R} 1$ & Upright, 'bottle brush'-shaped \\
\hline Alcyonidium 'latifolium' & BRY & $\mathrm{S}$ & $\mathrm{R} 1$ & Upright, flexible, fleshy \\
\hline Smittina antarctica & BRY & $\mathrm{T}$ & R1 & Erect, rigid \\
\hline Cellarinella nodulata & BRY & $\mathrm{T}$ & R1, R2, UD & Erect, rigid \\
\hline Cellarinella spp. & BRY & $\mathrm{T}$ & R1，R2，UD & Erect, rigid \\
\hline Tedania tantula & DEM & $\mathrm{T}$ & $\mathrm{R} 2$ & Upright, tubular-shaped \\
\hline Camptoplites tricornis & BRY & $\mathrm{B}$ & $\mathrm{R} 2$ & Flexible, dense bushy colony \\
\hline Paracellaria wandeli & BRY & $\mathrm{T}$ & $\mathrm{R} 2$ & Erect, rigid \\
\hline Rossella racovitzae & HEX & M & R2, UD & Upright, massive, barrel- to vase-shaped \\
\hline Cinachyra antarctica & DEM & M & $\mathrm{R} 2, \mathrm{UD}$ & Massive, spherical- to egg-shaped \\
\hline Cinachyra barbata & DEM & M & $\mathrm{R} 2, \mathrm{UD}$ & Massive, spherical- to ovoid-shaped \\
\hline ‘Yellow branches' & DEM & $\mathrm{T}$ & R2, UD & Irregularly branched \\
\hline Notisis spp. & GOR & $\mathrm{B}$ & $\mathrm{R} 2, \mathrm{UD}$ & Upright, bushy colonies \\
\hline Notoplites spp. & BRY & $\mathrm{B}$ & R2, UD & Flexible, dense bushy colony \\
\hline Hornea spp. & BRY & $\mathrm{T}$ & R2, UD & Erect rigid form \\
\hline Reteporella spp. & BRY & M & UD & Erect, rigid, reticulate \\
\hline Homaxinella spp. & DEM & $\mathrm{B}$ & & Tree-like \\
\hline Melicerita obliqua & BRY & $\mathrm{T}$ & & Erect, heavy calcified \\
\hline Primnoa resedaeformis & GOR & $\mathrm{T}$ & & Upright, arborescent form \\
\hline
\end{tabular}


scales. In our study, pioneer taxa were present during the first stages of recovery, which locally occurred with high abundance and patchy distribution (Table 3). This patchy distribution may explain the high heterogeneity of species composition during the first stages (Fig. 3). However, a certain similarity in composition occurred among the recovery stages, mainly between R0-R1 and R2-UD, due to the presence of 'structural' taxa within the stages (Table 3), showing differences in their coverage, number of patches and area. Studies on marine communities at other latitudes suggested that different successional trajectories converge towards the local resident assemblage (Berlow 1997, Chapman \& Underwood 1998, Sousa 2001). In our study, benthic composition converged in the later stages (Fig. 3). It is important to note the separation of the undisturbed

\begin{tabular}{|c|c|c|}
\hline Reproduction type & Growth rate/estimated age & Geographic area and depths \\
\hline Free-spawner, lecithotrophic & nd & Weddell Sea, from 100 to $800 \mathrm{~m}^{1}$ \\
\hline Supposedly free-spawner ${ }^{2,3}$ & $\begin{array}{l}\text { Fast-growing ascidian }{ }^{4} \\
\text { max. age } \sim 3 \mathrm{yr}^{5}\end{array}$ & $\begin{array}{l}\text { Antarctic and subantarctic }{ }^{3} \text { King George Island, } \\
\text { Bellingshausen Sea at } 30 \mathrm{~m}^{20}\end{array}$ \\
\hline $\begin{array}{l}\text { Brood protection of } \\
\text { young specimens }\end{array}$ & $\begin{array}{l}\text { Moderate, } 10.4 \text { yr for size } 4.36 \mathrm{~cm}^{2} \\
\left(0.41 \mathrm{~g} \mathrm{C}^{7}\right.\end{array}$ & $\begin{array}{l}\text { Terra Nova Bay, Ross Sea, from } 100 \text { to } 150 \mathrm{~m}^{7} \\
\text { Kapp Norvegia, Weddell Sea, continental shelf }\end{array}$ \\
\hline Brooding, lecithotrophic ${ }^{8}$ & nd & Weddell Sea, continental shelf ${ }^{9}$ \\
\hline External brooding, lecithotrophic ${ }^{10}$ & nd & Weddell Sea, continental shelf ${ }^{10}$ \\
\hline Supposedly brooding larvae ${ }^{11}$ & nd & Kapp Norvegia, Weddell Sea, from 65 to $433 \mathrm{~m}^{12}$ \\
\hline Supposedly brooding larvae ${ }^{11}$ & 9 growth rings ${ }^{13}$ & Kapp Norvegia, Weddell Sea, from 65 to $433 \mathrm{~m}^{12}$ \\
\hline Brooding, lecithotrophic ${ }^{8}$ & nd & Weddell Sea, continental shelf ${ }^{9}$ \\
\hline Brooding, lecithotrophic ${ }^{8}$ & nd & Weddell Sea, continental shelf ${ }^{9}$ \\
\hline $\begin{array}{l}\text { Brooding, lecithotrophic } \\
\text { fragmentation }\end{array}$ & $\begin{array}{l}\text { Moderate (from related species } \\
\text { C. wartesi, max. age } \sim 9 \mathrm{yr}^{15} \text { ) }\end{array}$ & $\begin{array}{l}\text { Weddell Sea, continental shelf } \\
\quad \text { Signy Island, South Orkney Islands, above } 50 \mathrm{~m}^{15}\end{array}$ \\
\hline $\begin{array}{l}\text { Brooding, lecithotrophic } \\
\text { fragmentation }^{14}\end{array}$ & $\begin{array}{l}\text { Moderate (from related species } \\
\text { C. wartesi, max. age } \sim 9 \mathrm{yr}^{15} \text { ) }\end{array}$ & $\begin{array}{l}\text { Weddell Sea, continental shelf } \\
\text { Ross Sea, from } 115 \text { to } 870 \mathrm{~m}^{14} \\
\text { Signy Island, South Orkney Islands, above } 50 \mathrm{~m}^{15}\end{array}$ \\
\hline $\begin{array}{l}\text { Brooding, lecithotrophic } \\
\text { fragmentation }^{8}\end{array}$ & $\begin{array}{l}\text { Moderate (from related species } \\
\text { C. wartesi, max. age } \sim 9 \mathrm{yr}^{15} \text { ) }\end{array}$ & $\begin{array}{l}\text { Weddell Sea, continental shelf } \\
\text { Ross Sea, from } 115 \text { to } 870 \mathrm{~m}^{14} \\
\text { Signy Island, South Orkney Islands, above } 50 \mathrm{~m}^{15}\end{array}$ \\
\hline Free swimming larvae ${ }^{16}$ & nd & Kapp Norvegia, Weddell Sea, from 99 to 1125 m $^{16}$ \\
\hline Brooding, lecithotrophic ${ }^{8}$ & nd & Weddell Sea, continental shelf ${ }^{9}$ \\
\hline $\begin{array}{l}\text { Brooding, lecithotrophic }{ }^{8} \\
\text { budding }{ }^{17,18}\end{array}$ & $\begin{array}{l}\text { nd } \\
\text { very slow for large individuals }{ }^{17}\end{array}$ & $\begin{array}{l}\text { Weddell Sea, continental shelf } \\
\text { McMurdo Sound, Ross Sea; below } 30 \mathrm{~m}^{17}\end{array}$ \\
\hline Free swimming larve $\mathrm{e}^{16}$ & Fast for small individuals ${ }^{17}$ & Kapp Norvegia, Weddell Sea, from 99 to $1125 \mathrm{~m}^{16}$ \\
\hline $\begin{array}{l}\text { Low larval dispersal }{ }^{16} \\
\text { outgrowth forms }^{18}\end{array}$ & Very slow, $2 \mathrm{~cm}$ in $10 \mathrm{yr}^{17}$ & $\begin{array}{l}\text { McMurdo Sound, Ross Sea; below } 30 \mathrm{~m}^{17} \\
\text { Aquarium mantenaince }{ }^{18}\end{array}$ \\
\hline Low larval dispersal ${ }^{16}$ & $\begin{array}{l}\text { Very slow (from related species } \\
\text { Tetilla leptoderma) }\end{array}$ & $\begin{array}{l}\text { McMurdo Sound, Ross Sea; below } 30 \mathrm{~m}^{17} \\
\text { Kapp Norvegia, Weddell Sea, from } 99 \text { to } 1125 \mathrm{~m}^{16}\end{array}$ \\
\hline nd & nd & Kapp Norvegia, Weddell Sea, from 99 to 1125 m$^{16}$ \\
\hline Supposedly brooding larvae ${ }^{11}$ & nd & Kapp Norvegia, Weddell Sea, from 65 to $433 \mathrm{~m}^{12}$ \\
\hline Brooding, lecithotrophic ${ }^{8}$ & nd & Weddell Sea, continental shelf ${ }^{9}$ \\
\hline Lecithotrophic larvae $^{8}$ & nd & Weddell Sea, continental shelf ${ }^{9}$ \\
\hline Brooding, lecithotrophic larvae $e^{2,3}$ & nd & Antarctic and subantarctic ${ }^{3}$ \\
\hline Brooding, lecithotrophic larvae $\mathrm{e}^{2,3}$ & nd & Antarctic and subantarctic ${ }^{3}$ \\
\hline Budding $^{13,19}$, low larval dispersal ${ }^{19}$ & $\begin{array}{l}\text { Very slow }^{17} \\
\text { Centuries } ~ 500 \mathrm{yr}^{17}\end{array}$ & $\begin{array}{l}\text { McMurdo Sound, Ross Sea, Below } 30 \mathrm{~m}^{17,19} \\
\text { Atka Bay and Kapp Norvegia, Weddell Sea, } \\
\text { from } 117 \text { to } 245 \mathrm{~m}^{13}\end{array}$ \\
\hline Supposedly free-spawner ${ }^{16}$ & nd & Kapp Norvegia, Weddell Sea, from 99 to $1125 \mathrm{~m}^{16}$ \\
\hline Brooding, lecithotrophic ${ }^{8}$ & nd & Weddell Sea, continental shelf ${ }^{9}$ \\
\hline Brooding, lecithotrophic ${ }^{8}$ & $\begin{array}{l}\text { Moderate (Cellaria incula } \\
\text { rate }=8 \mathrm{~mm} \mathrm{yr}^{-1} \text {, max. age } \sim 15 \mathrm{yr}^{20} \text { ) }\end{array}$ & $\begin{array}{l}\text { Weddell Sea, continental shelf } \\
\text { Weddell Sea, from } 433 \text { to } 535 \mathrm{~m}^{20}\end{array}$ \\
\hline Brooding, lecithotrophic ${ }^{8}$ & nd & Weddell Sea, continental shelf ${ }^{9}$ \\
\hline Low larval dispersion ${ }^{17}$ & Fast-growing sponge $\mathrm{e}^{17}$ & McMurdo Sound, Ross Sea; between15-30 $\mathrm{m}^{17}$ \\
\hline Brooding, lecithotrophic ${ }^{21}$ & $\begin{array}{l}\text { Moderate growth }\left(4.5 \mathrm{~mm} \mathrm{yr}^{-1}\right. \\
\text { max. age } \sim 50 \mathrm{yr})^{21}\end{array}$ & Weddell Sea, continental shelf ${ }^{21}$ \\
\hline Larval production ${ }^{22}$ & $\begin{array}{l}\text { Moderate growth }\left(1.6-2.3 \mathrm{~cm} \mathrm{yr}^{-1}\right. \\
\text { max. age } \sim 112 \mathrm{yr})^{22}\end{array}$ & $\begin{array}{l}\text { North Atlantic and North Pacific Oceans, } \\
\text { below } 100 \mathrm{~m}^{22}\end{array}$ \\
\hline
\end{tabular}

\footnotetext{
${ }^{13} \mathrm{~N}$. Teixidó (unpubl. data); ${ }^{14}$ Winston $(1983) ;{ }^{15}$ Barnes $(1995 b) ;{ }_{i}{ }^{16}$ Barthel \& Gutt (1992); ${ }^{17}$ Dayton $(1979) ;{ }^{18}$ Barthel et al. $(1997) ;$ ${ }^{19}$ Dayton et al. (1974); ${ }^{20}$ Brey et al. (1999); ${ }^{21}$ Brey et al. (1998); ${ }^{22}$ Andrews et al. (2002)
} 
assemblage, characterised by the long-lived volcanoshaped hexactinellid species and the round demosponge Cinachyra barbata (Fig. 3). The separation within this assemblage (UD) shows that local dominance of sponges reduces diversity and shape complexity patterns at the small scale (Teixidó et al. 2002).

\section{Patterns of cover by different growth-forms}

Growth-form cover patterns sharply changed along the recovery sequence, where bush-like morphology characterised the early stages (R0 and R1), tree-like the advance stage (R2) and mound-like the undisturbed stage (UD) (Fig. 5). Sheet, tree and mound-like forms are predicted to be generally superior in competition to bushes (Jackson 1979), and are therefore expected to dominate the later stages. Our results were consistent with this prediction, although the contribution of sheet-like forms was relatively low in the later stages (R2 and UD). The presence of tree-like forms was relatively high through the recovery stages with a great number of patches and moderate area values at $\mathrm{R} 2$, whereas the dominance of the mound-like form was evident in UD (Fig. 5). Overall, our results on the cover predominance of tree and mound categories along the later stages are in accordance with a previous study on shallow Antarctic benthos at Signy Island (Barnes 1995a). These successful strategies might respond to the apparent high sedimentation rates and lateral transport of organic matter in the Weddell Sea (Elverhøi \& Roaldset 1983, Fahrbach et al. 1992, Gleitz et al. 1994, Park et al. 1999). Tree- and mound-like forms have efficient access to the particles in the water column and escape from burial by settling sediment (Jackson 1979). This may also be an explanation for the low dominance of sheet-like and runner-like forms, although the latter form is predicted to be successful in disturbed environments due to fast growth and high fecundity (Jackson 1979, Fahrig et al. 1994, Karlson et al. 1996). Despite the inferior competitive capacity of bush morphology (Connell \& Keough 1985), this category occupied the space constantly over the recovery sequence, showing low NP with intermediate to large area values (Fig. 5). This presence may be related to epibiotic relationships (Dayton et al. 1970, Gutt \& Schickan 1998), avoiding competition with better competitors. It is likely that these organisms, which have a refuge-oriented strategy may rapidly occupy the space between large organisms with slower growth rates (Buss 1979). Finally, the dominance of different growth forms may influence the diversity within the community (Figs. $2 \& 5$ ). For example, mound-like forms represent massive species of sponges, anemones, ascidians and pterobranchs. However, these organisms may differ with the external surface (e.g. smooth surface, presence of spicules) that will influence the development of epibenthic-associated fauna. Therefore, from our results on growth forms, we cannot generalise that the predominance of a growth form reduces diversity. This phenomenon will depend on the dominance of organisms with a smooth surface that will not favour the settlement of sessile epibenthic organisms on their surface and in their surroundings (e.g. due to chemical defences).

\section{Life-history traits during recovery}

Comprehensive studies of Antarctic benthic species are scarce, but the available information may be useful in better understanding the variation of life-history patterns through the recovery process. It should be considered that the pace of reproduction and growth of Antarctic marine invertebrates is generally very slow (Clarke 1983, Pearse et al. 1991, Arntz et al. 1994). This characteristic may have a strong effect on all aspects of a species' life-history and should determine the time needed for a species or a community to recover after disturbance.

The data in Table 4 show that the ascidian Molgula pedunculata and the demosponge Homaxinella spp. (this latter species grows very fast and is a pioneer species, Dayton 1979, Gutt \& Piepenburg 2003) have the highest growth rates with intermediate and short distance dispersal, respectively (Table 4). In addition, Homaxinella spp. exhibited intense larval settlement in shallow communities of the Ross Sea (Dayton 1979). This characteristic and the fast growth seem to favour recolonisation of shallow zones regularly disturbed by anchor ice. The demosponge Stylocordyla borealis sexually develops young complete sponges incubated in the mother's body, which settle in the close vicinity, thereby showing low dispersability (Sarà et al. 2002). Based on growth models, Gatti (2002) calculated an estimated age of $10.4 \mathrm{yr}$ for a body area of $4.4 \mathrm{~cm}^{2}$. In R0, we found smaller individuals of $S$. borealis with a mean area of $1.2 \mathrm{~cm}^{2}$, suggesting a younger age. The upright species of gorgonians Primnoella spp. and Primnoisis antarctica appeared locally with high abundance in the R1 stage (Table 3). P. antarctica showed 9 growth rings in the centre of the basal part of its calcareous axis (Table 4). A related species, the deep gorgonian Primnoa resedaeformis, revealed annual growth ring formation and a maximum estimated age of $112 \mathrm{yr}$ using growth and radiometric analyses (Andrews et al. 2002). Considering this rate, P. antarctica found in R1 could have an estimated age of $9 \mathrm{yr}$. Further studies using sclerochronological techniques should provide valuable information on growth rates 
and longevity of Antarctic benthic species. In general, these data suggest that the early recovery stages R0 and R1 may represent approximately up to $10 \mathrm{yr}$ of recolonisation once the pioneer species arrived.

The erect and heavily calcified Cellarinella wartesi and Melicerita obliqua (this latter species is a pioneer coloniser) (Gutt \& Piepenburg 2003) showed annual skeletal growth check lines and are considered longlived perennials with a maximum estimated age of 9 and 50 yr, respectively (Barnes 1995b, Brey et al. 1998). Both species produce lecithotrophic larvae; in addition, cellarinellids also reproduce by fragmentation and further growth (Winston 1983, Barnes 1995b). Furthermore, the amount of embryos per colony in M. obliqua was reported to be about an order of magnitude higher than in the cellarinellids (Winston 1983). These different dispersal strategies within bryozoans may determine their success in recolonising disturbed areas.

This study showed that massive vase- and sphericalshaped hexactinellids and demosponges are big and abundant in areas of low disturbance, and have a patchy distribution (Table 3). These sponges exhibited the lowest growth rates, the longest lifespan, the biggest area and short-distance dispersal (philopatry) because of asexual reproduction (budding) (Table 4). However, Dayton (1979) observed high reproduction activity by bud formation and rapid growth of small individuals in Rossella racovitzae in McMurdo Sound. The author also noted that, within this species, growth rates were highly variable and weak water currents accounted for the localised and dense patches of small individuals. Concerning offspring dispersal, Maldonado \& Uriz (1999) showed that asexual fragments of Mediterranean sponges transported undeveloped larvae, thus enhancing their dispersal ability and genetic variability among populations. Within this context, this strategy could be a reasonable mechanism for recolonisation of disturbed areas in Antarctica. We acknowledge that new studies on reproduction, larval dispersal and recruitment patterns using genetic tools will substantially improve our knowledge on the recovery of benthos after iceberg disturbance.

Iceberg disturbance is a common event in the evolutionary history of Antarctic benthic habitats and is among the most severe disturbances in the world (Clarke \& Crame 1992, Gutt \& Starmans 2001). This study has, for the first time, developed a quantitative description for community recovery after iceberg disturbance in Antarctic benthos. We have provided new insights into the composition and abundance of sessile benthic organisms along the recovery gradient. In addition, these recovery stages were characterised by different growth forms, which revealed a change as recovery proceeded. Our study pointed out the importance of 'structural taxa' in determining community composition and organisation at each stage, and their life-history traits corroborated the general trends in the distribution during Antarctic recovery. The combination of this study and large-scale spatial and temporal monitoring can greatly contribute to a better representation of the response of Antarctic benthic communities to iceberg disturbance. Detecting and understanding long-term patterns of Antarctic benthic communities will be a major challenge due to the long lifespan of many of these species.

Acknowledgements. We thank P. López (gorgonians), E. Rodriguez (actinians), M. Zabala (bryozoans), A. Ramos (ascidians) and M. C. Gambi (polychaetes) for taxonomic assistance. D. Piepenburg facilitated his photographic material from Stn 042 and 211 (ANT XV/III). Critical comments of T. Brey and T. Cope are greatly acknowledged. The manuscript improved after the comments of R. T. Paine and 3 anonymous referees. N.T. was funded by a Bremen University fellowship.

\section{LITERATURE CITED}

Airoldi L (2000) Effects of disturbance, life histories, and overgrowth on coexistence of algal crusts and turfs. Ecology 81(3):798-814

Andrews AH, Cordes EE, Mahoney MM, Munk K, Coale KH, Cailliet GM, Heifetz J (2002) Age, growth and radiometric age validation of a deep-sea, habitat-forming gorgonian (Primnoa resedaeformis) from the Gulf of Alaska. Hydrobiologia 471:101-110

Arntz WE, Gutt J (1997) The expedition ANTARKTIS XIII/3 (EASIZ I) of RV 'Polarstern' to the eastern Weddell Sea in 1996. Ber Polarforsch 249:1-148

Arntz WE, Gutt J (1999) The expedition ANTARKTIS XV/3 (EASIZ II) of RV 'Polarstern' to the eastern Weddell Sea in 1998. Ber Polarforsch 301:1-229

Arntz WE, Brey T, Gallardo VA (1994) Antarctic zoobenthos. Oceanogr Mar Biol Annu Rev 32:241-304

Barnes DKA (1995a) Sublittoral epifaunal communities at Signy Island, Antarctica. II. Below the ice-foot zone. Mar Biol 121:565-572

Barnes DKA (1995b) Seasonal and annual growth in erect species of Antarctic bryozoans. J Exp Mar Biol Ecol 188: 181-191

Barthel D, Gutt J (1992) Sponge associations in the eastern Weddell Sea. Antarct Sci 4(2):137-150

Barthel D, Tendal O, Gatti S (1997) The sponge fauna of the Weddell Sea and its integration in benthic processes. In: Arntz WE, Gutt J (eds) The expedition ANTARKTIS XIII/3 (EASIZ I) of RV 'Polarstern' to the eastern Weddell Sea in 1996. Ber Polarforschung 249, Bremerhaven, p 44-52

Bathmann U, Fischer G, Müller PJ, Gerdes D (1991) Shortterm variations in particulate matter sedimentation off Kapp Norvegia, Weddell Sea, Antarctica: relation to water mass advection, ice cover, plankton biomass and feeding activity. Polar Biol 11:185-195

Berlow EL (1997) From canalization to contingency: Historical effects in a successional rocky intertidal community. Ecol Monogr 67(4):435-460

Bray JR, Curtis JZ (1957) An ordination of the upland forest communities of Southern Wisconsin. Ecol Monogr 27: $325-349$

Brenner M, Buch BH, Cordes S, Dietrich L and 6 others (2001) The role of iceberg scours in niche separation within the 
Antarctic genus Trematomus. Polar Biol 24:502-507

Brey T, Gutt J, Mackensen A, Starmans A (1998) Growth and productivity of the high Antarctic bryozoan Melicerita obliqua. Mar Biol 132:327-333

Brey T, Gerdes D, Gutt J, Mackensen A, Starmans A (1999) Growth and age of the Antarctic bryozoan Cellaria incula on the Weddell Sea shelf. Antarct Sci 11(4):408-414

Buss LW (1979) Habitat selection, directional growth and spatial refuges: why colonial animals have more hiding places. In: Larwood G, Rosen BR (eds) Biology and systematics of colonial organisms. Academic Press, London, p 459-497

Cancino JM, Torres F, Moyano HI (2002) Larval release pattern in Antarctic bryozoans. In: Wyse Jackson PN, Buttler JC, Spencer Jones ME (eds) Bryozoan studies 2001. Balkema Publishers, Lisse, p 67-72

Carmack EC, Foster TD (1977) Water masses and circulation in the Weddell Sea. In: Dunbar MJ, Alberta C (eds) Polar Oceans: Proc Polar Oceans Conf, May 1974. Arctic Institute of North America, Montreal, p 167-177

Chapman MG, Underwood AJ (1998) Inconsistency and variation in the development of rocky intertidal algal assemblages. J Exp Mar Biol Ecol 224:265-488

Clarke A (1983) Life in cold water: the physiological ecology of polar marine ectotherms. Oceanogr Mar Biol Annu Rev 21:341-453

Clarke A, Crame JA (1992) The southern ocean benthic fauna and climate change: an historical perspective. Phil Trans $\mathrm{R}$ Soc Lond (B) 338:299-309

Clarke KR (1993) Non-parametric multivariate analyses of changes in community structure. Aust J Ecol 18:117-143

Clarke KR, Gorley RN (2001). Primer v5: user manual. PrimerE, Plymouth

Clarke KR, Warwick RM (1994) Change in marine communities: an approach to statistical analysis and interpretation. Natural Environmental Research Council, Plymouth

Coates AG, Jackson JBC (1985) Morphological themes in the evolution of clonal and aclonal marine invertebrates. In: Jackson JBC, Buss LW, Cook RE (eds) Population biology and evolution of clonal organisms. Yale University Press, New Haven, p 67-106

Connell JH, Keough MJ (1985) Disturbance and patch dynamics of subtidal marine animals on hard substrata. In: Pickett STA, White PS (eds) The ecology of natural disturbance and patch dynamics. Academic Press, London, p 125-151

Connell JH, Slatyer RO (1977) Mechanisms of succession in natural communities and their role in community stability and organization. Am Nat 111:1119-1144

Connell JH, Hughes TP, Wallace CC (1997) A 30-year study of coral abundance, recruitment, and disturbance at several scales in space and time. Ecol Monogr 67(4):461-488

Dayton PK (1971) Competition, disturbance, and community organization: the provision and subsequent utilization of space in a rocky intertidal community. Ecol Monogr 41(4): 351-389

Dayton PK (1979) Observations of growth, dispersal and population dynamics of some sponges in McMurdo Sound, Antarctica. Colloq Int Cent Natl Rech Sci 291:271-282

Dayton PK, Robilliard GA, Paine RT (1970) Benthic faunal zonation as a result of anchor ice at McMurdo Sound, Antarctica. In: Holdgate MW (ed) Antarctic ecology. Academic Press, New York, p 244-258

Dayton PK, Robilliard GA, Paine RT, Dayton LB (1974) Biological accommodation in the benthic community at McMurdo Sound, Antarctica. Ecol Monogr 44:105-128

Discovery Committee Colonial Office (1929-1980) Dis- covery Reports, Vol 1-37. University Press, Cambridge

Dunbar RB, Anderson JB, Domack EW (1985) Oceanographic influence on sedimentation along the Antarctic continental shelf. Antarct Res Ser 43:291-312

Elverhøi A, Roaldset E (1983) Glaciomarine sediments and suspended particulate matter, Weddell Sea shelf, Antartica. Polar Res 1:1-21

Fahrbach E, Rohardt G, Krause G (1992) The Antarctic Coastal Current in the southeastern Weddell Sea. Polar Biol 12:171-182

Fahrig L, Coffin DP, Lauenroth WK, Shugart HH (1994) The advantage of long-distance clonal spreading in high disturbed habitats. Evol Ecol 8:172-187

Field JG, Clarke KR, Warwick RM (1982) A practical strategy for analysing multispecies distribution patterns. Mar Ecol Prog Ser 8:37-52

Gambi MC, Giangrande A, Patti FP (2000) Comparative observations on reproductive biology of four species of Perkinsiana (Polychaeta: Sabellidae: Sabellinae). Bull Mar Sci 67(1):299-309

Gambi MC, Patti FP, Micaletto G, Giangrande A (2001) Diversity of reproductive features in some Antarctic polynoid and sabellid polychaetes, with a description of Demonax polarsterni sp.n. (Polychaeta, Sabellidae). Polar Biol 24: 883-891

Gatti S (2002) The role of sponges in high Antarctic carbon and silicon cycling - a modelling approach. PhD thesis, Bremen University. Ber Polar Meeresforsch 434, Bremerhaven

Gerdes D, Hilbig B, Montiel A (2003) Impact of iceberg scouring on macrobenthic communities in the high Antarctic Weddell Sea. Polar Biol 26:295-301

Giangrande A, Geraci S, Belmonte G (1994) Life-cycle and life-history diversity in marine invertebrates and the implications in community dynamics. Oceanogr Mar Biol Annu Rev 32:305-333

Gili JM, Arntz WE, Filipe P, López-González P, Orejas C, Ros JD, Teixidó N (1999) The role of benthic suspension feeders in Antarctic communities. In: Arntz WE, Gutt J (eds) The expedition ANTARKTIS XV/3 (EASIZ II) of RV 'Polarstern' to the eastern Weddell Sea in 1998. Ber Polarforsch 301:30-83

Gili JM, Coma R, Orejas C, López-González J, Zabala M (2001) Are Antarctic suspension-feeding communities different from those elsewhere in the world? Polar Biol 24:473-485

Gleitz M, Bathmann U, Lochte K (1994) Build-up and decline of summer phytoplankton biomass in the eastern Weddell Sea, Antarctica. Polar Biol 14:413-422

Grassle JF, Grassle JP (1974) Opportunistic life histories and genetic systems in marine benthic polychaetes. J Mar Res 32(2):253-284

Gutt J (2000) Some 'driving forces' structuring communities of the sublittoral Antarctic macrobenthos. Antarct Sci 12(3): 297-313

Gutt J, Piepenburg D (2003) Scale-dependent impacts of catastrophic disturbances by grounding icebergs on the diversity of Antarctic benthos. Mar Ecol Prog Ser 253:77-83

Gutt J, Schickan T (1998) Epibiotic relationships in Antarctic benthos. Antarct Sci 10(4):398-405

Gutt J, Starmans A (1998) Structure and biodiversity of megabenthos in the Weddell and Lazarev Seas (Antarctica): ecological role of physical parameters and biological interactions. Polar Biol 20:229-247

Gutt J, Starmans A (2001) Quantification of iceberg impact and benthic recolonisation patterns in the Weddell Sea (Antarctica). Polar Biol 24:615-619 
Gutt J, Starmans A, Dieckmann G (1996) Impact of iceberg scouring on polar benthic habitats. Mar Ecol Prog Ser 137: 311-316

Hayward PJ (1995) Antarctic cheilostomatous Bryozoa. Oxford University Press, Oxford

Hempel G (1985) On the biology of polar seas, particularly the Southern Ocean. In: Gray JS, Christiansen ME (eds) Marine biology of polar regions and effects of stress on marine organisms. Wiley, Chichester, p 3-31

Hughes TP, Jackson JB (1980) Do corals lie about their age? Some demographic consequences of partial mortality, fission, and fusion. Science 209:713-715

Hughes TP, Jackson JB (1985) Population dynamics and life histories of foliaceous corals. Ecol Monogr 55(2):141-166

Hughes TP, Tanner JE (2000) Recruitment failure, life histories, and long-term decline of Caribbean corals. Ecology 81(8):2250-2263

Huston MA (1994) Biological diversity: the coexistence of species on changing landscapes. Cambridge University Press, Cambridge

Jackson JBC (1979) Morphological strategies in sessile animals. In: Jackson JBC, Buss LW, Cook RE (eds) Population biology and evolution of clonal organisms. Yale University Press, New Haven, p 499-555

Karlson RH, Hughes TP, Karlson SR (1996) Density-dependent dynamics of soft coral aggregations: the significance of clonal growth and form. Ecology 77(5):1592-1599

Knust R, Arntz WE, Boche M, Brey T and 5 others (2003) Iceberg scouring on the eastern Weddell Sea shelf (Antarctica): a benthic system shaped by physical disturbances? In: Huiskes AHL, Gieskes WWC, Rozema J, Schorno RML, van der Vies SM, Wolff WJ (eds) Antarctic biology in a global context. Backhuys Publishers, Leiden, p 96-101

Kowalke J, Tatián M, Sahade R, Arntz W (2001) Production and respiration of Antarctic ascidians. Polar Biol 24:663-669

Kruskal JB, Wish M (1978) Multidimensional scaling. Sage Publications, Beverly Hills

Lee HJ, Gerdes D, Vanhove S, Vincx M (2001) Meiofauna response to iceberg disturbance on the Antarctic continental shelf at Kapp Norvegia (Weddell Sea). Polar Biol 24:926-933

Maldonado M, Uriz MJ (1999) Sexual propagation by sponge fragments. Nature 298:476

McCook LJ (1994) Understanding ecological community succession: causal models and theories, a review. Vegetatio 110:115-147

McCook LJ, Chapman ARO (1997) Patterns and variations in natural succession following massive ice-scour of a rocky intertidal seashore. J Exp Mar Biol Ecol 214:121-147

Monniot C, Monniot F (1983) Ascidies antarctiques et subantarctiques: morphologie et biogéographie. Série A, Zoologie. Mémoires du Muséum National d'Histoire Naturelle. Nouvelle Série 125:1-168

Nelson DM, Smith WO Jr, Muench RD, Gordon LI, Sullivant CW, Husby DM (1989) Particulate matter and nutrient distributions in the ice-edge zone of the Weddell Sea: relationship to hydrography during the late summer. Deep- Sea Res 36:191-209

Newell RC, Seiderer LJ, Hitchcock DR (1998) The impact of dredging works in coastal waters: a review of the sensitiv- ity to disturbance and subsequent recovery of biological resources on the sea bed. Oceanogr Mar Biol Annu Rev $36: 127-178$

Paine RT, Levin SA (1981) Intertidal landscapes: disturbance and the dynamics of pattern. Ecol Monogr 51(2):145-178

Paine RT, Tegner MJ, Johnson EA (1998) Compounded perturbations yield ecological surprises. Ecosystems 1: $535-545$

Park MG, Yang SR, Kang S-H, Chung KH, Shim JH (1999) Phytoplankton biomass and primary production in the marginal ice zone of the northwestern Weddell Sea during austral summer. Polar Biol 21:251-261

Pearse JS, McClintock JB, Bosch I (1991) Reproduction of Antarctic benthic marine invertebrates: Tempos, modes, and timing. Am Zool 31:65-80

Pickett STA, White PS (1985) The ecology of natural disturbance and patch dynamics. Academic Press, London

Rauschert M (1991) Ergebnisse der faunistischen Arbeiten im Benthal von King George Island (Südshetlandinseln, Antarktis). Ber Polarforsch 76, Bremerhaven

Sachs L (1984) Angewandte Statistik. Springer, Berlin

Sackville Hamilton N, Schmid B, Harper JL (1987) Lifehistory concepts and the population biology of clonal organisms. Proc R Soc Lond (B) 232:35-57

Sarà A, Cerrano C, Sarà M (2002) Viviparous development in the Antarctic sponge Stylocordyla borealis Loven, 1868. Polar Biol 25:425-431

Sieg J, Wägele JW (1990) Fauna der Antarktis. Parey, Berlin

Sokal RR, Rohlf FJ (1981) Biometry: the principles and practice of statistics in biological research. Freeman, San Francisco

Sousa WP (1980) The responses of a community to disturbances: the importance of successional age and species' life histories. Oecologia 45:72-81

Sousa WP (2001) Natural disturbance and the dynamics of marine benthic communities. In: Bertness MD, Gaines SD, Hay ME (eds) Marine community ecology. Sinauer Associates, Sunderland, p 85-130

Starmans A, Gutt J, Arntz WE (1999) Mega-epibenthic communities in Antarctic and Arctic shelf areas. Mar Biol 135 $269-280$

STATISTICA for Windows (2000) Computer program manual. StatSoft, Tulsa

Svane IB, Young CM (1989) The ecology and behaviour of ascidian larvae. Oceanogr Mar Biol Annu Rev 27:45-90

Teixidó N, Garrabou J, Arntz WE (2002) Spatial pattern quantification of Antarctic benthic communities using Landscape indices. Mar Ecol Prog Ser 242:1-14

Thomson CW, Murray J (1880-1889) Report on the scientific results of the voyage of H.M.S. Challenger during the years 1873-76, Zoology, Vol 1-32. Neill, Edinburgh

Tréguer P, Jacques G (1992) Dynamics of nutrients and phytoplankton, and fluxes of carbon, nitrogen and silicon in the Antarctic Ocean. Polar Biol 12:149-162

Winston JD (1983) Patterns of growth, reproduction and mortality in bryozoans from the Ross Sea, Antarctica. Bull Mar Sci 33(3):688-702

Zabala M, Orejas C, Alvà V (1997) Bryozoans of the Weddell Sea. In: Arntz WE, Gutt J (eds) The expedition ANTARKTIS XIII/3 (EASIZ I) of RV 'Polarstern' to the eastern Weddell Sea in 1996. Ber Polarforsch 249:1-148 
Appendix 1. Sessile benthic organisms identified along the different stages of recolonisation (from younger to older stages: R0, R1 and R2, and undisturbed assemblage: UD). +: presence; -: absence



